\title{
Competition for space between encrusting excavating Caribbean sponges and other coral reef organisms
}

\author{
Mateo López-Victoria ${ }^{1,2}$, Sven Zea ${ }^{2, *}$, Ernesto Weil ${ }^{3}$ \\ ${ }^{1}$ Instituto de Investigaciones Marinas y Costeras - INVEMAR, and ${ }^{2}$ Departamento de Biología and Centro de Estudios en \\ Ciencias del Mar, CECIMAR, Universidad Nacional de Colombia, INVEMAR, Cerro Punta de Betín, A.A. 1016, \\ Santa Marta, Colombia \\ ${ }^{3}$ Islas Magueyez Marine Laboratory, Department of Marine Sciences, University of Puerto Rico, PO Box 908, \\ Lajas 00667, Puerto Rico
}

\begin{abstract}
Encrusting and excavating Caribbean sponges Cliona aprica, C. caribbaea and C. tenuis (Hadromerida: Clionaidae) aggressively undermine and displace live coral tissue. To establish modes and rates of lateral advance into neighboring organisms, 171 sponge individuals were studied for $13 \mathrm{mo}$. Sponge advancement into live coral, via excavation underneath boundary polyps, occurred only when the 2 confronted at an angle of $\geq 180^{\circ}$. Sponges stopped or retreated when coral upward and inward growth at the boundary closed the angle between the coral and sponge, placing polyps out of reach of excavating tissue. At a straight angle of confrontation, $C$. tenuis advanced into coral at higher rates than the other 2 sponge species. Its advance was more pronounced into Diploria strigosa than into Siderastrea siderea. Sponge undermining continuously opened space for transient settlement of turf algae and for accumulation of sediments. Corallivory at the sponge-coral boundary did not imply greater rates of sponge advance, but probably did contribute to coral bioerosion. Massive corals escaped sponge undermining by upward growth, their ability to do so depended partly on defensive mechanisms. Foliose and platy corals escaped by overtopping. Rates of sponge advance into substrata incrusted and overgrown by algae were in general lower than into live coral, while sponges lost space to some encrusting invertebrates.
\end{abstract}

KEY WORDS: Competition - Excavating sponges $\cdot$ Cliona $\cdot$ Coral reefs $\cdot$ Caribbean $\cdot$ Corallivory $\cdot$ Turf algae $\cdot$ Reflex angle

Resale or republication not permitted without written consent of the publisher

\section{INTRODUCTION}

Sponges that simultaneously excavate and encrust carbonate substrata also compete for space with corals and other reef organisms (Glynn 1997, Schönberg \& Wilkinson 2001, Rützler 2002). In the Greater Caribbean, 3 species of excavating sponges of the family Clionaidae (Porifera, Hadromerida), namely Cliona aprica Pang, C. caribbaea Carter, and C. tenuis Zea \& Weil (taxonomy reviewed in Zea \& Weil 2003), have been increasing in abundance during the last 25 to $30 \mathrm{yr}$, occupying extensive areas of reef space and aggressively undermining and displacing live coral tissue (see López-Victoria \& Zea 2005 and references therein). These sponges are brown to brown-black incrustations, ranging from fields of closely spaced, isolated or fused papillae to a continuous thin veneer of tissue. Although these 3 species excavate and penetrate only the first 1.5 to $2 \mathrm{~cm}$ of the substratum, they are capable of spreading laterally at rates of up to $19 \mathrm{~cm} \mathrm{yr}^{-1}$ (Rützler 2002, López-Victoria et al. 2003). When they encounter live coral, these sponges perforate the skeleton immediately below the live tissue, eroding the polyp's skeletal support. The sponge tissue front is often preceded by pioneering excavating tissue filaments or threads $(1-2 \mathrm{~mm}$ in diameter, $\mathrm{mm}$ to $\mathrm{cm}$ 
apart) that can penetrate immediately below live coral tissue (>4 cm) (Schönberg \& Wilkinson 2001, LópezVictoria et al. 2003). Despite having aggressive defense mechanisms such as sweeper tentacles and mesenteric filaments with stinging cells (Lang \& Chornesky 1990), corals cannot always avoid the attack from below by these sponges (see Rützler 2002, LópezVictoria et al. 2003).

We carried out detailed observations of the phenomenon in marked and unmarked sponge individuals, to establish: (1) in what circumstances is there a lateral advance by the sponges into corals, (2) how do rates of advance vary between sponge species and according to the live neighbor (coral species, algal functional groups, other invertebrates), and (3) how do different species of live corals respond to the advance by the sponges and what is the final result?

\section{MATERIALS AND METHODS}

The present study was carried out at San Andrés Island and Islas del Rosario Archipelago, Colombia (Fig. 1). San Andrés is an oceanic island located in the SW Caribbean and surrounded by an extensive calcareous platform with barrier, terrace and lagoon reefs (Zea et al. 1998). Rosario is a complex of low islands and cays located on the Colombian continental shelf, surrounded by fringing, terrace, and lagoon reefs (Cendales et al. 2002). Encrusting and excavating Cliona spp. sponges are common in these islands. C. aprica is dark brown to black and occurs as fields of closely spaced papillae (up to $4 \mathrm{~mm}$ in diameter), which are partly to almost completely fused, and can reach a diameter of up to about $50 \mathrm{~cm}$. C. caribbaea is amber brown or gray brown and completely covers the excavated substratum with a thick tissue (up to $2 \mathrm{~mm}$ ), reaching a diameter of up to $1 \mathrm{~m}$.



Fig. 1. Coral reef areas and sites where this study was carried out
C. tenuis forms a thin, continuous veneer of rather transparent brown tissue, through which the underlying carbonate structures can be discerned; individual sizes may reach 3 to $5 \mathrm{~m}$ in diameter. For detailed descriptions, synonymies, and for general ecology of the 3 species see Zea $\&$ Weil (2003). To follow the annual lateral advance of these sponges into neighboring organisms, a total of 180 individuals of the 3 sponge species were marked at 5 stations at San Andrés (6 to $17 \mathrm{~m}$ deep, all 3 sponge species), and at 2 stations at Islas del Rosario (4 to $6 \mathrm{~m}$, only C. tenuis) (Fig. 1) in May and June 2001. Steel nails were driven into the periphery of each sponge in places that were in contact with or close to various reef organisms. On waterproof paper we drew the outline of each sponge and surrounding organisms, the location of the nails, and other characteristics to help future identification. Features at the boundary, such as presence of other organisms, sediment, and fish bite marks were recorded. Underwater photographs were taken for most marked individuals to aid in the analysis. Five categories of neighbors were established: live coral tissue (lco, by species), macroalgae (malg), turf algae (talg), crustose coralline algae (calg), and other invertebrates (oinv, by species). Six and 13 mo after marking, distance from the border of the sponge to the outer edge of each nail was measured to the nearest $0.5 \mathrm{~mm}$, using plastic calipers. For each nail, a single per year distance advanced or receded by the sponge was calculated. Where more than one nail had been placed against a given neighbor category in the same sponge, their advances were averaged in a single datum. Data were thus distance advanced (positive lateral advance) or receded (negative lateral advance) by a sponge individual against a category of neighbor. Of the 180 marked sponge individuals, lateral advance data were obtained from 171; 3 died, and 6 were never relocated. Statistical comparisons of per year lateral advance by category of neighbor, within or between sponge species, were carried out by Kruskal-Wallis and Mann-Whitney $U$ non-parametric tests. Student $t$-tests were used to determine if mean advances were significantly different from zero. Data in the text are presented as means $\pm 1 \mathrm{SE}$.

\section{RESULTS}

\section{Confrontation with stony corals}

Noticeable sponge advance into live coral tissue only occurred when there was an approximately straight to reflex angle $\left(\geq 180^{\circ}\right)$ between the sponge and coral planes at their boundaries. Upon closer inspection, we realized that sponge excavating tissue and its 
filaments could penetrate and undermine directly beneath live coral polyps only at these angles of confrontation. Undermining was best carried out at a straight angle $\left(\sim 180^{\circ}\right)$ (Figs. 2a \& 3a,b). As a consequence of both the lateral sponge excavation and a slight upward coral growth, the sponge plane was 3 to $10 \mathrm{~mm}$ lower than the coral plane. Encrusting corals were temporarily able to evade the sponge by growing over it as a shingle, but on occasion the sponge was able to break through at some distance from the coral edge, erode the shingle and continue its advance. There was a reflex angle of confrontation $\left(>180^{\circ}\right)$ when the top of massive or foliose corals had been colonized by a sponge (Fig. 2b). As a result of its upward and outward growth, the coral tended to form a slightly elevated lip surrounding the sponge. Sponge filaments were then at times able to break through as papillae and emerge in between live coral polyps, and the lip was eventually eroded (Figs. 2b \& 3c). The process could repeat itself several times, the lip being reformed to be eroded again. The sponge thus expanded intermittently more or less horizontally over a flat coral top. In contrast, wherever the coral had been able to grow upwards above the sponge plane and inwards towards the sponge, forming a dome that closed the confrontation angle $\left(<180^{\circ}\right)$, polyps were out of reach from the excavating sponge tissue and its filaments (Figs. 2c \& $3 d)$. The sponge did not advance, and occasionally even receded as the coral dome started to grow in

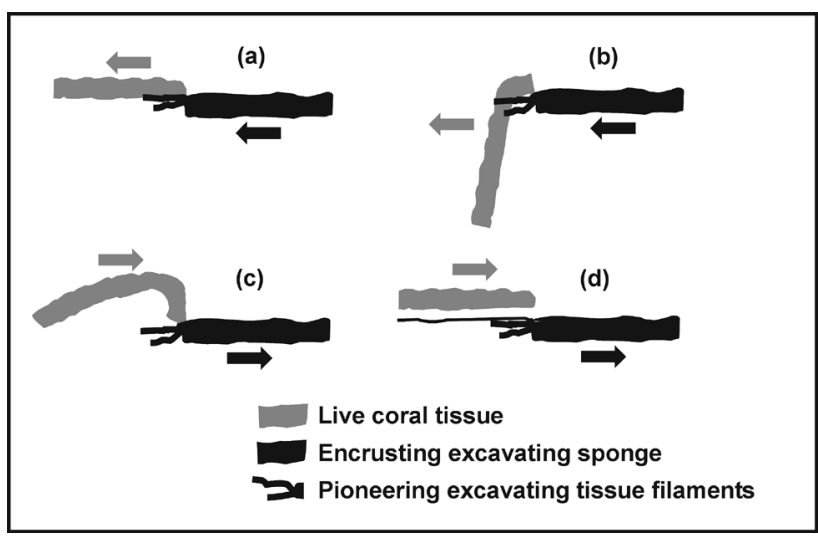

Fig. 2. Schematic model of those cases in which the confrontation between encrusting excavating sponges and live coral tissue results in advance or retreat by the sponge. Arrows indicate advance or retreat. (a) Straight $\left(\sim 180^{\circ}\right)$ angle between coral and sponge planes; excavating tissue reaches directly underneath coral polyps, continuously eroding their support. (b) Reflex $\left(>180^{\circ}\right)$ angle between coral and sponge planes; excavating tissue breaks open intermittently in between live coral polyps. (c) $<180^{\circ}$ angle between coral and sponge planes; polyps are out of reach of excavating tissue by upward and inward coral growth at the boundary. (d) Sponge and coral in different substrata; sponge tissue extensions must bridge the gap to reach the coral diameter. We had also marked cases in which the coral and the sponge were adjacent to each other but were growing on different substrata (Fig. 2d). The coral, usually growing as a shingle or a mound, frequently advanced over the sponge. However, the sponge occasionally reached the coral skeleton from below and broke open through live coral tissue (in which case it advanced further into live coral depending on the angle of confrontation).

According to the aforementioned descriptions, at a straight angle of confrontation, mean rates of sponge lateral advance into live coral tissue were positive and significantly different from zero for all 3 sponge species (2-tailed $t$-test, $\mathrm{p}<0.05 ; H_{0}$ : mean advance $=0$, Fig. 4, lco). Of the 79 cases of straight angle, 8 showed no advance at all and only 1 retreated. Rates of advance were more pronounced for Cliona tenuis $\left(4.3 \pm 0.6 \mathrm{~cm} \mathrm{yr}^{-1}\right)$, followed by $C$. caribbaea $\left(1.8 \pm 0.4 \mathrm{~cm} \mathrm{yr}^{-1}\right)$, and $C$. aprica $\left(1.3 \pm 0.3 \mathrm{~cm} \mathrm{yr}^{-1}\right)$ (Fig. 4). For other angles of confrontation $\left(>180^{\circ},<180^{\circ}\right)$, and when sponge and coral were in different substrata (difs), lateral advance data clustered around zero. Of the $8>180^{\circ}$ angle cases there was sponge advance in 3 and retreat in 1 . In the 2 sponge species in which hypothesis testing was meaningful ( $\mathrm{n} \geq 6), C$. aprica and $C$. tenuis mean advances at angles $<180^{\circ}$ were not significantly different from zero, being respectively $0.1 \pm 0.1$ and $-0.4 \pm 0.15 \mathrm{~cm} \mathrm{yr}^{-1}(\mathrm{n}=$ 18 for both, Fig. 4). Within a given sponge individual growing on a coral colony there could be portions of its perimeter actively advancing, while other portions could be rather static and even retreating. In some cases, a sponge had been able to undermine and overgrow a coral colony completely, but in others the coral had escaped, surrounding the sponge with domeshaped outgrowths.

In general, lateral advance into all coral species at a straight angle was greater for Cliona tenuis than for the other 2 sponge species. Siderastrea siderea was the only coral for which there were data on the 3 sponge species. Statistical comparisons showed that $C$. tenuis had significantly higher positive advance rates into this coral (3.5 \pm $0.6 \mathrm{~cm} \mathrm{yr}^{-1}$ ) than the other 2 sponges, which in turn were not significantly different from each other (C. aprica 1.2 \pm 0.5 , C. caribbaea $1.2 \pm 0.3 \mathrm{~cm} \mathrm{yr}^{-1}$; Kruskal-Wallis, $H=$ 14.2, p = 0.0008; Mann-Whitney Upairwise tests) (Fig. 5). Statistical comparisons of sponge advance at a straight angle between coral species were possible only for C. tenuis growing into Diploria strigosa and S. siderea. C. tenuis tended to advance farther into D. strigosa $\left(\right.$ mean $\left.5.9 \pm 1.7 \mathrm{~cm} \mathrm{yr}^{-1}\right)$ than into $S$. siderea $(3.5 \pm 0.6 \mathrm{~cm}$ $\left.\mathrm{yr}^{-1}\right)$, although at rates not significantly different (MannWhitney test, $W=21.5, \mathrm{p}=0.20$ (Fig. 5).

Frequently, there was a belt, up to about $1 \mathrm{~cm}$ wide, of turf algae and sediments at the sponge-coral boundary. Partly smothered or sometimes empty boun- 



Fig. 3. Cliona aprica, C. caribbaea and C. tenuis. Examples of confrontations between encrusting excavating sponges and neighbors. (a) C. tenuis vs. coral Diploria labyrinthiformis at initial marking, $180^{\circ}$ angle of confrontation; (b) C. tenuis vs. D. labyrinthiformis 6 mo later; (c) C. aprica vs. S. siderea 6 mo after marking (nails on right mark original boundary), $>180^{\circ}$ angle of confrontation, with an advancing front of papillae breaking open beyond the main sponge-coral border; (d) C. tenuis vs. coral D. strigosa, $<180^{\circ}$ angle of confrontation, the surviving coral growing as a dome; (e) C. aprica vs. coral Montastraea cavernosa, with turf algae and sediments at the boundary; (f) C. tenuis vs. coral Siderastrea siderea with fish bite marks (white scraped area) in the coral at the boundary with the sponge; $(\mathrm{g}) \mathrm{C}$. tenuis vs. crustose coralline algae, 13 mo after marking (nails [arrows] mark original boundary); and (h) C. aprica vs. various macro algae (Lobophora variegata and Dictyota sp.). Horizontal width of field is approximately $16.4 \mathrm{~cm}$ for (a), (b), (f), (g) and (h); $7.2 \mathrm{~cm}$ for (c) and (e); $80 \mathrm{~cm}$ for (d) 

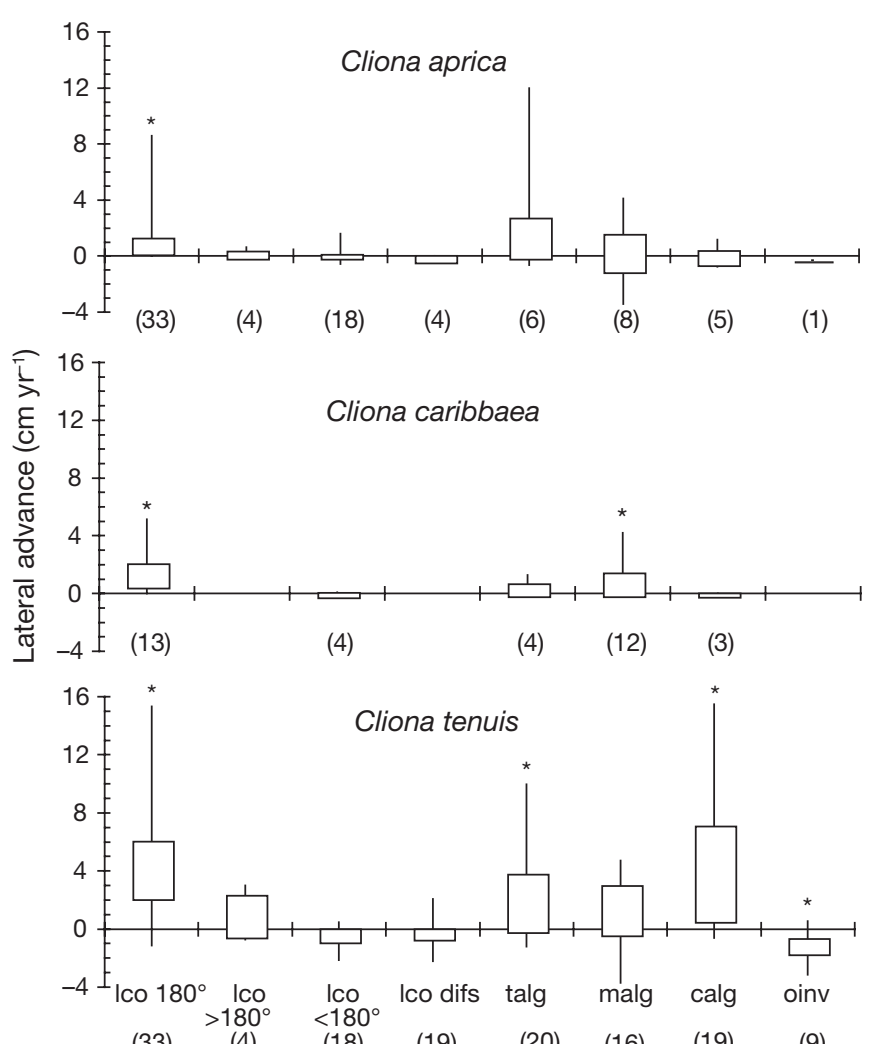

Neighbor categories

Fig. 4. Cliona aprica, C. caribbaea and C. tenuis. Rates of lateral advance (positive $=$ growth, negative $=$ retreat) by neighbor category. An asterisk indicates mean significantly different from zero (2-tailed $t$-test, $\mathrm{p}<0.05)$. Data are length of lateral advance by a sponge individual into a given neighbor (averaged when more than 1 nail had been placed at the boundary). Boxes represent range of variation between the first and third quartile ( 25 to $75 \%$ of the cumulative frequency of data); the vertical line represents the range between the minimum and maximum. Number of sponge individuals for each category is given in parentheses. Five categories of neighbors are: live coral tissue (lco, by species, and in different substrata, difs), macroalgae (malg), turf algae (talg), crustose coralline algae (calg), and other invertebrates (oinv, by species)

dary polyps were common (Fig. 3e). In the absence of this belt, the sponge and coral tissues would almost be touching. Comparisons of the rates of sponge lateral advance at a straight angle $\left(180^{\circ}\right)$ in the presence versus the absence of a turf belt could be carried out for Cliona aprica and C. caribbaea (Fig. 6). Advancement rates tended to be more pronounced in both sponge species when there was a turf belt rather than when it was absent, but they were significantly different only for C. caribbaea (Mann-Whitney $U$-test, $W=37.0, \mathrm{p}=$ 0.03 , mean $2.7 \pm 0.6$ with turfs and $0.7 \pm 0.2 \mathrm{~cm} \mathrm{yr}^{-1}$ without turfs) (Fig. 6).

Parrotfish (Scaridae, especially Sparisoma viride) and butterfly fish (Chaetodontidae) were seen actively

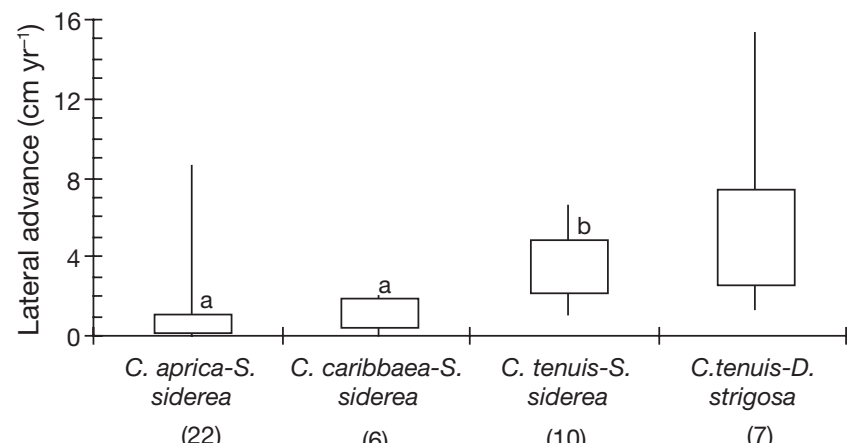

(6)

(10)

(7)

Sponge-coral combination

Fig. 5. Cliona aprica, C. caribbaea and C. tenuis. Rates of lateral advance, at $180^{\circ}$ angle of confrontation between the sponge and coral planes (see Fig. 2a), into corals Siderastrea siderea and Diploria strigosa. Advance rates of the sponges into the coral $S$. siderea with different letters $(\mathrm{a}, \mathrm{b})$ were significantly different (Kruskal-Wallis and Mann-Whitney tests, $\mathrm{p}<0.05$ ). Advance rates of $C$. tenuis into $D$. strigosa and $S$. siderea were not significantly different (Mann-Whitney test, $\mathrm{p}<0.05)$. Number of sponge individuals for each category is given in parentheses. See Fig. 4 for explanation of bars and sample sizes

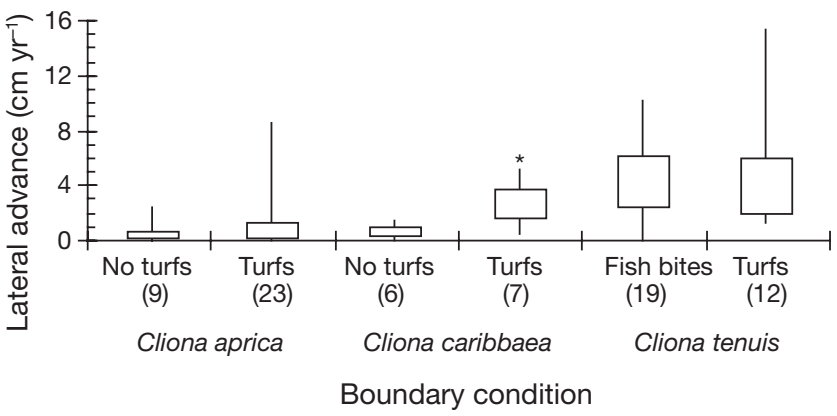

Fig. 6. Cliona aprica, C. caribbaea and C. tenuis. Rates of lateral advance, at $180^{\circ}$ angle of confrontation between the sponge and coral planes (see Fig. 2a), as a function of the condition (presence or absence of a turf belt, fish bites) at the coral-sponge boundary. Asterisk denotes significantly faster advance when comparing boundary conditions within each species (Mann-Whitney tests, $\mathrm{p}<0.05$ ). Number of sponge individuals for each category is given in parentheses.

See Fig. 4 for explanation of bars and sample sizes

feeding on the boundary coral polyps which were confronted with Cliona tenuis. This was rarely observed for the other 2 sponge species. Biting removed the corals' prominent skeletal elements. Parrotfish bite marks on the coral sometimes stretched out in a continuous band, up to $2-4 \mathrm{~cm}$ wide, along the boundary with the sponge (Fig. 3f), especially in Siderastrea siderea. Freshly bitten bands were clean, but in older ones turf algae had started to settle; both were occupied by the sponge in the period between observations. Some boundaries showed fresh bites every time they were examined. But overall, lateral advance in 
boundaries with obvious fish bite marks had no significant effect on the speed at which $C$. tenuis advanced, in comparison to boundaries with no obvious fish bites, which were instead occupied by turfs (Fig. 6, MannWhitney $U$-test, $W=113.5, \mathrm{p}=1.0$, means $4.6 \pm 0.6$ and $4.9 \pm 1.1 \mathrm{~cm} \mathrm{yr}^{-1}$ respectively)

The presence of a $<180^{\circ}$ angle at a sponge-coral boundary was assumed to be the result of past evasion by the coral through upward and inward growth of the boundary polyps beyond the reach of excavating tissue (Fig. 2c). To ascertain whether coral species varied in this assumed ability to evade the advancing sponges we re-examined the proportion of marked boundaries for each coral-sponge confrontation type (as in Fig. 2) for each coral species. In Montastraea cavernosa, 82\% of its marked boundaries had an angle of confrontation $<180^{\circ}$ (except for a single case of Cliona caribbaea at a $180^{\circ}$ angle), while in Siderastrea siderea, most had a $180^{\circ}$ angle, with just $9 \%$ being $<180^{\circ}$ (Fig. 7). The percentage of marked boundaries at $<180^{\circ}$ for all other coral species varied from 0 to $43 \%$ (data not shown; too sparse for comparisons). These results imply that $M$. cavernosa was more successful than $S$. siderea and perhaps other coral species in limiting sponge growth.

\section{Confrontation with algae}

There was much variation within and between sponge species in rates of advance into substrata colonized by the 3 categories of algae (Figs. $3 \& 4$ ). While Cliona aprica did not advance significantly ( $t$-test, $\mathrm{p}<$ 0.05 ) into any of the 3 categories of algae, C. caribbaea did so into macroalgae (malg, $0.9 \pm 0.4 \mathrm{~cm} \mathrm{yr}^{-1}$, but data were too sparse for evaluation of the other algal categories), and $C$. tenuis into turf algae (talg, $2.4 \pm$ $0.8 \mathrm{~cm} \mathrm{yr}^{-1}$ ), and crustose coralline algae (calg, $4.4 \pm$ $1.0 \mathrm{~cm} \mathrm{yr}^{-1}$ ) (Fig. 4). C. tenuis both advanced and retreated into macroalgae, resulting in a mean advance not significantly different from zero (Fig. 4). C. tenuis rates of advance into crustose coralline algae were comparable to those into corals at a straight $\left(180^{\circ}\right)$ angle (Figs. $3 g$ \& 4$)$.

\section{Confrontation with other sponges and colonial invertebrates}

Cliona tenuis significantly lost space to encrusting invertebrates (overall mean distance $-1.2 \pm 1.0 \mathrm{~cm} \mathrm{yr}^{-1}$, $t$-test, $\mathrm{p}<0.05$, Fig. 4). There were not enough marked cases to allow for statistical comparisons. Space competitors included the sponge Chondrilla nucula (Fig. 8a), the encrusting gorgonian Erythropodium caribaeorum (Fig. 8b), the colonial zoanthids Palythoa


Fig. 7. Cliona aprica, C. caribbaea and C. tenuis. Proportion of marked boundaries for each coral-sponge confrontation types (see Fig. 2) found in the corals Montrastraea cavernosa and Siderastrea siderea. Number of marked boundaries (each representing 1 nail) for each type of confrontation is given in parentheses. difs: different substrata

caribaeorum (Fig. 8c) and Zoanthus pulchellus, and the colonial tunicate Trididemnum solidum (Fig. 8d). The overgrowth resulted in bleaching and death of the overgrown sponge tissue.

\section{DISCUSSION}

Our results confirm that the studied encrusting and excavating sponges are successful competitors for space against reef corals. In addition to previous studies, we found that lateral sponge advance depends on the way sponge and coral tissues face each other. The sponges were able to advance significantly only while the sponge and the coral planes were confronted at an approximately straight $\left(180^{\circ}\right)$ angle, a position in which excavating sponge tissue is able to continuously erode the polyp's skeletal support. At other angles of confrontation, coral polyps are either reached intermittently by sponge excavating tissue $\left(>180^{\circ}\right)$, or are altogether out of their reach $\left(<180^{\circ}\right)$.

Because environmental conditions in which the 3 sponge species live were not the same (see Zea \& Weil 2003, López-Victoria \& Zea 2005), we cannot directly ascribe the differences in overall or coral-specific growth rates to sponge species-specific abilities, e.g. the faster advance rates by Cliona tenuis into Siderastrea siderea. Nevertheless, regardless of coral species, Cliona tenuis generally showed the fastest advance rates of the 3 studied species. The rates measured for this species were of about the same magnitude as 



Fig. 8. Cliona aprica, C. caribbaea and C. tenuis overgrown by other invertebrates. (a) C. caribbaea overgrown by sponge Chondrilla nucula; (b) C. tenuis overgrown by the encrusting gorgonian Erythropodium caribaeorum; (c) C. tenuis overgrown by the colonial zoanthid Palythoa caribaeorum; and (d) C. aprica overgrown by the colonial tunicate Trididemnum solidum. Approx. horizontal width of the field for (a) is $30 \mathrm{~cm}$, (b) $16.4 \mathrm{~cm}$, (c) $1 \mathrm{~m}$ and (d) $60 \mathrm{~cm}$

those measured in other areas (up to $9.2 \mathrm{~cm} \mathrm{yr}^{-1}$ in Grand Cayman, Acker \& Risk 1984, as C. caribbaea light colored form; means 4.1 to $9.1 \mathrm{~cm} \mathrm{yr}^{-1}$ in Belize, Rützler 2002, as C. caribbaea). In contrast, another Caribbean, thinly encrusting clionaid, Pione lampa (formerly placed under Cliona) advanced over live coral at slower rates (1.2 to $2.8 \mathrm{~cm} \mathrm{yr}^{-1}$, Rützler 1975), perhaps owing to its lack of symbiotic zooxanthellae (Rützler 2002).

A close association between more pronounced rates of sponge advance and the presence of turf algae and sediments at the boundary imply that coral tissue displacement continuously opens space for opportunistic settlers, resulting in the transient formation of a turf algal belt; instead, when advancing little, the sponges close the gap, narrowing the turf band. Smothering of boundary polyps by the turf belt and accumulated sediments (Roy 2004a,b) may in turn weaken further coral polyps and aid in sponge advance. From our data, however, we cannot separate sponge undermining from turf smothering in causing coral death. Obvious signs of corallivory at coral-Cliona tenuis boundaries, on the other hand, do not seem to have an overall effect on the speed at which this sponge advances. Its advancement thus appears to be independent of events occurring at the coral and sponge surfaces thanks to its strong undermining. Instead, the impact of corallivory on the overall sponge bioerosion may be substantial if the difference in height observed between sponge and coral surfaces is thought to be a consequence of fish bites, instead of, or in addition to, the lateral leveling by the sponge. Indeed, the parrotfish, Sparisoma viride, an important reef bioeroder, makes deep feeding scars in corals and reef substrata (Scoffin et al. 1980, Bellwood \& Choat 1990). Perhaps fish are attracted to sponge-live coral boundaries, where they can more easily dislodge coral fragments or remove tissue from the weakened coral polyps.

The Australian encrusting and excavating sponge, Cliona orientalis, caused more erosion and grew faster in those corals that had denser skeletons, lower pore volume and more structural barriers (Schönberg 2002, 2003). However, differences in skeletal density cannot explain the more pronounced rates of advance of Cliona tenuis into Diploria strigosa than into Siderastrea siderea, as density is slightly higher in the latter coral (1.61 vs. $1.57 \mathrm{~g} \mathrm{~cm}^{3}$ in D. strigosa, Hughes 1987). However, equal sized blocks of $D$. strigosa took longer to cut 
with a diamond saw than those of S. siderea (M. LópezVictoria unpubl. data). As D. strigosa defensive abilities are ranked higher than those of $S$. siderea (Logan 1984), this trait doesn't explain differences in sponge advance. Perhaps sponge advancement is favored by the more irregular and less dense external morphology of $D$. strigosa, in comparison to the more even and dense $S$. siderea. Although the skeletal prominences of $D$. strigosa may be more easily removed by corallivorous fish, as mentioned above, processes at the coral surface do not seem to affect advance by this sponge.

The sponges are stopped or forced to retreat when part or the entire coral border is able to grow upwards and inwards (towards the sponge), closing the angle of confrontation to $<180^{\circ}$. Small scale factors such as variation in coral colony topography or presence of skeletal or organic barriers (Rützler 1975, Schönberg 2002, 2003), or environmental factors such as temperature (Rützler 2002), may slow sponge excavation rates, allowing corals to escape. Both rates of upward growth and external defensive mechanisms of the corals (i.e. sweeper tentacles, mesenteric filaments, mucus, Lang \& Chornesky 1990) may be involved in withstanding the actions of the sponges. According to our data, the massive coral, Montastraea cavernosa, may be able to escape sponge undermining by upward growth more frequently than other corals. This coral ranks high in defensive mechanisms (Lang 1973, Logan 1984). It may injure and thus slow down a neighboring sponge due to its large polyps, and by extending defensive appendages to a greater distance than other corals with smaller polyps (Lang \& Chornesky 1990). Indeed, this coral can successfully resist overgrowth by space competitors such as Palythoa caribaeorum (Suchanek \& Green 1981), and prevent colonization by explants of the encrusting excavating sponge Pione lampa (McKenna 1997). On the other side of the spectrum, Siderastrea siderea, a massive coral ranking low in aggressiveness, showed many fewer boundaries which had escaped sponge undermining, and was also found to be more susceptible to overgrowth by P. caribaeorum (Suchanek \& Green 1981). Crustose, foliose, and platy corals with edges growing laterally, are less likely to escape sponge undermining by upward growth (= thickening) than massive corals. Instead, some of them use low overtopping, i.e. growing laterally over the neighbor as a shingle, shading it to escape undermining (cf. Lang \& Chornesky 1990). On occasion, however, the sponge may bridge the gap with tissue extensions reaching the coral from below (López-Victoria \& Zea 2004).

The rather low rates of sponge retreat from corals, when the confrontation angle is $<180^{\circ}$, shows that for corals, recovery of space occurs at a much slower rate than its loss. This is obvious in massive corals as the lateral recovery of space occurs while the surviving coral portions form domes and grow in diameter (e.g. Grauss \& Macintyre 1982). In the long term, 3-dimensional growth of corals may compensate 2-dimensional space lost to sponges, and for that matter, to other encrusting organisms. Our observation of coral domes surrounding encrusting excavating sponges supports this notion.

In well illuminated situations, the studied sponges can gain space from algae of various kinds, although at rates generally lower than in live corals. A greater difficulty to undermine reef substrata heavily modified by diagenesis, and infilling and incrusting by numerous organisms (Acker \& Risk 1985, López-Victoria 2003) may explain this difference. Coral skeletons are more porous than modified substrata as described above and allow the sponge to grow into pores, without the need to excavate (Schönberg 2002, 2003, authors' unpubl. obs.). Shading by foliose macro algae may account for a greater number of cases in which there was loss of space by the sponges compared against the other categories of algae.

The non-coralline invertebrate neighbors that gained space from the studied sponges are known for their ability to overgrow most reef organisms thanks to fast lateral growth rates, and perhaps to the aid of noxious secondary metabolites (e.g. Bak et al. 1981, Suchanek \& Green 1981, Vicente 1990, Fenical \& Pawlik 1991). Being fleshy, tough and elastic, these invertebrates do not easily lose support even if their external borders are not attached directly to the substratum when growing over live sponge tissue. When they advance further, the sponge is smothered and the invader can take hold on the newly available reef surface.

\section{CONCLUSIONS}

Rates of lateral advance or retreat of the encrusting excavating sponges, Cliona aprica, C. caribbaea and C. tenuis vary with the type of neighbor. Significant advance into live corals occurs only while the sponge and coral planes are confronted at an approximately straight $\left(180^{\circ}\right)$ angle, a position in which excavating sponge tissue continuously reaches coral polyps from below. At greater angles, excavating filaments break intermittently through live coral on the far side. Evasion by corals of undermining tissue takes place wherever the boundary polyps grow upwards and inwards, closing the angle of confrontation. At straight angles, lateral advance rates were generally greater for Cliona tenuis than for the other 2 sponge species, but we could not attribute these differences to either environmental or sponge-specific abilities. Advance by C. tenuis is more pronounced into Diploria strigosa than into Siderastrea siderea, but known differences in density, skeletal or defensive abilities between the 2 corals cannot account for these results. Lateral sponge advance 
continuously opens space for the transient settlement of turf algae and the accumulation of sediments, which in turn may further weaken coral boundary polyps. Corallivory by fish at $C$. tenuis boundaries do not accelerate sponge advance but may be contributing to the overall coral bioerosion. Massive corals that manage to escape sponge undermining by upward growth form domes which surround the sponge, and would eventually recover lost space. Among these, the ability to evade sponges seems to be related to the strength of defensive mechanisms. Foliose and platy corals may escape by overtopping the sponges, although they may on occasion be reached from below. The sponges' rates of advance are generally faster into live coral tissue than when bordering substrata with crustose, turf and foliose algae. In contrast, the sponges lose space to common macroinvertebrate overgrowers of the reef, which form sheet-like encrustations.

Acknowledgements. This work was funded by Colombian Science Fund-COLCIENCIAS (grant 110109-10387), University of Puerto Rico Sea Grant Program, INVEMAR, and Universidad Nacional de Colombia. A. Chaves-Fonnegra, F. Parra-Velandia, L. Banda, B. Ossa, N. Guevara and J. M. Medrano are thanked for help during the field work. R Vieira (CEINER Oceanarium) offered us hospitality and logistical support at Islas del Rosario. D. Rozo and P. Lozano of INVEMAR's GIS Lab helped with the map and figures. Three anonymous reviewers greatly helped to improve the quality of the manuscript. Contribution 898 of INVEMAR and 253 of the Centro de Estudios en Ciencias del Mar - CECIMAR and the Graduate Program in Marine Biology of the Universidad Nacional de Colombia, Faculty of Sciences.

\section{LITERATURE CITED}

Acker KL, Risk MJ (1985) Substrate destruction and sediment production by the boring sponge Cliona caribbaea on Grand Caiman Island. J Sediment Petrol 55(5):705-711

Bak RPM, Sybesma J, van Duyl FC (1981) The ecology of the tropical compound ascidian Trididemnum solidum. II. Abundance, growth and Survival. Mar Ecol Prog Ser 6: 43-52

Bellwood DR, Choat JH (1990) A functional analysis of grazing in parrotfishes (family Scaridae): the ecological implications. Environ Biol Fish 28:189-214

Cendales MH, Zea S, Díaz JM (2002) Geomorfología y unidades ecológicas del complejo arrecifal de Islas del Rosario e Isla Barú (Mar Caribe, Colombia). Rev Acad Colomb Cienc 26:497-510

Fenical W, Pawlik JR (1991) Defensive properties of secondary metabolites from the Caribbean gorgonian coral Erythropodium caribaeorum. Mar Ecol Prog Ser 75:1-8

Glynn P (1997) Bioerosion and coral reef growth: a dinamic balance. In: Birkeland C (ed) Life and death of coral reefs. Chapman \& Hall, New York

Graus RR, Macintyre IG (1982) Variation in growth forms of the reef coral Montastrea annularis (Ellis and Solander): a quantitative evaluation of growth response to light distribution using computer simulation. Smithson Contrib Mar Sci 12:441-464

Editorial responsibility: Otto Kinne (Editor-in-Chief), Oldendorf/Luhe, Germany
Hughes TP (1987) Skeletal density and growth form of corals. Mar Ecol Prog Ser 35:259-266

Lang JC (1973) Interespecific aggression by scleractinian corals. 2 . Why the race is not only to the swift. Bull Mar Sci 23:260-279

Lang JC, Chornesky EH (1990). Competition between scleractinian reef corals - a review of mechanisms and effects. In: Dubinsky Z (ed) Ecosystems of the world, 25. Coral reefs. Elsevier, Amsterdam, p 209-252

Logan A (1984) Interspecific aggression in hermatypic corals from Bermuda. Coral Reefs 3:131-138

López-Victoria M (2003) Interacciones entre esponjas excavadoras del complejo Cliona aprica - C. langae C. caribbaea y corales pétreos en el Caribe colombiano. MSc thesis, Universidad Nacional de Colombia, Bogotá

López-Victoria M, Zea S (2004) Storm-mediated coral colonization by an excavating Caribbean sponge. Clim Res 26: 251-256

López-Victoria M, Zea S (2005) Current trends of space monopolization by encrusting excavating sponges on Colombian coral reefs. PSZN I: Mar Ecol 26:33-41

López-Victoria M, Zea S, Weil E (2003) New aspects on the biology of the excavating sponge complex Cliona caribbaea-C. langae-C. aprica. Boll Mus Ist biol Univ Genova 68:425-432

McKenna SA (1997) Interactions between the boring sponge, Cliona lampa and 2 hermatypic corals from Bermuda. Proc 8th Int Coral Reef Symp Panama 2:1369-1374

Roy REA (2004a) Turf/algal sediment (TAS) mats: a chronic stressor on scleractinian corals in Akumal, México. PhD dissertation, University of Texas at Austin, TX

Roy RE (2004b) Akumal's reefs: Stony coral communities along the developing Mexican Caribbean coastline. Rev Biol Trop 52:869-881

Rützler K (1975) The role of burrowing sponges in bioerosion. Oecologia (Berl) 19:203-216

Rützler K (2002) Impact of crustose clionid sponges on Caribbean reef corals. Acta Geol Hisp 37:61-72

Schönberg CHL (2002) Substrate effects on the bioeroding demosponge Cliona orientalis. 1. Bioerosion rates. PSZN:I Mar Ecol 23:313-326

Schönberg CHL (2003) Substrate effects on the bioeroding demosponge Cliona orientalis. 2. Substrate colonization and tissue growth. PSZN I: Mar Ecol 24:59-74

Schönberg CHL, Wilkinson CR (2001) Induced colonization of corals by a clionid bioeroding sponge. Coral Reefs 20:69-76

Scoffin TP, Stearn CW, Boucher D, Frydl P, Hawkins CM, Hunter IG, MacGeachy JK (1980) Calcium carbonate budget of a fringing reef on the west coast of Barbados. Part II. Erosion, sediments and internal structure. Bull Mar Sci 30: 475-508

Suchanek TH, Green DJ (1981) Interspecific competition between Palythoa caribaeorum and other sessile invertebrates on St. Croix reef, U.S. Virgin Islands. Proc 4th Int Coral Reef Symp, Manila 2:679-684

Vicente VP (1990) Overgrowth activity by the encrusting sponge Chondrilla nucula on a coral reef in Puerto Rico. In: Rützler K (ed) New perspectives in sponge biology. Smithsonian Institution Press, Washington, DC, p 436-442

Zea S, Weil E (2003) Taxonomy of the Caribbean excavating sponge species complex Cliona caribbaea - C. aprica C. langae (Porifera, Hadromerida, Clionaidae). Caribb J Sci 39:348-370

Zea S, Geister J, Garzón-Ferreira J, Díaz JM (1998) Biotic changes in the reef complex of San Andrés Island (Southwestern Caribbean Sea, Colombia) occurring over nearly three decades. Atoll Res Bull 456:1-30

Submitted: June 3, 2004; Accepted: October 18, 2005

Proofs received from author(s): March 21, 2006 